\title{
SENGKARUT FORMALISASI SYARIAH DI INDONESIA
}

\author{
Mohamad Mahrusillah \\ STISNU Nusantara Tangerang Raya \\ mmahrusillah@gmail.com
}

\begin{abstract}
This paper tries to trace the dispute (pro-konta) on sharia formalization in Indonesia and presents the description how far the sharia formalization is implemented. Regardless to the dispute, the difficulties to implement the formalization is no country in the world implement the sharia totally. This research is used social and historical approaches and also literary reviews on legislation, journal, quoting ulama' ideas and their activities and others related opinions.
\end{abstract}

Keywords: Formalization; Sharia; Islam

\begin{abstract}
Abstrak
Artikel ini berupaya untuk melacak kekacauan (baca: pro-konta) mengenai formalisasi syariat di Indonesia, dan mencoba memberi gambaran seberapa jauh peluang formalisasi syariat ini disetujui. Namun terlepas dari adanya pro dan kontra mengenai gagasan formalisasi syariat, kesulitan dalam mewujudkan formalisasi tersebut adalah hingga saat ini tidak ada satu pun negara di dunia yang menerapkan formalisasi syariat secara utuh. Penelitian ini menggunakan pendekatan sosial historis dengan menggunakan penelitian kepustakaan melalui pengumpulan dan studi literatur, legislasi, jurnal, dan mengutip pendapat ulama dan aktivis serta pendapat terkait lainnya.
\end{abstract}

Kata Kunci: Formalisasi; Syariat; Islam 


\section{PENDAHULUAN}

Dalam konteks negara modern, model pemahaman Syariah memiliki perspektif yang berbeda dan telah menjadi subjek perhatian dan penelitian yang dilakukan oleh berbagai pihak. Menerapkan hukum Syariah dalam konteks modern tentu tidak semudah menerapkannya dalam konteks klasik. Pada zaman klasik, ketika konsep negara masih berdasarkan agama, praktik hukum Syariah seperti memotong ke tangan pencuri, melempar batu atau mengumpulkan jizyah untuk non-Muslim, tidak menimbulkan terlalu banyak masalah karena secara politik sangat memungkinkan. Tetapi dalam konteks saat ini, ketika negara tidak lagi didasarkan pada agama, implementasinya tidak dapat sepenuhnya identik dengan penerapannya dalam konteks klasik, seperti banyak perubahan dalam aturan politik global. Sebagai contoh, dunia modern mengakui konsep negara nasionalis; Kesetaraan warga negara tanpa memandang ras, etnis, atau agama di depan hukum. ${ }^{1}$

Islam, sebagai agama yang diterima oleh mayoritas penduduk Indonesia, memiliki dampak besar pada cara hidup masyarakat Indonesia. Dari sudut pandang orang Indonesia, hukum Islam adalah bagian penting dari ajaran agama, dan Islam juga merupakan ruang untuk mengekspresikan pengalaman keagamaan yang paling penting dan menjadi cerminan dari kesinambungan dan identitas sejarah. Demikian pula, hukum Islam di Indonesia dapat dinyatakan dalam formulasi yang sangat sederhana bahwa hukum Islam di Indonesia pada dasarnya adalah norma-norma hukum berdasarkan syariat Islam yang tumbuh dan berkembang dalam kehidupan orang-orang sepanjang sejarah. dari Indonesia. Ia lahir dari perkawinan normatif (Syariah) dengan konten lokal Indonesia pada umumnya. ${ }^{2}$

Sebagai negara dengan mayoritas Muslim, Indonesia telah memenuhi keinginan politisi masa lalu di negeri ini berjuang untuk mengintegrasikan prinsip-prinsip dasar Islam sebagai ideologi negara. Bagaimanapun, langkah-langkah politisi Muslim bukan tanpa hambatan. Kesulitan yang dihadapi para politisi muslim saat itu adalah memasukan tujuh kata dalam Piagam Jakarta (Ketuhanan dengan kewajiban menjalankan syari'at Islam bagi pemeluknya) ke dalam institusi negara. Pada akhirnya gagasan itu ditolak oleh mayoritas suara di Parlemen. Piagam Jakarta adalah dokumen yang dimaksudkan untuk dijadikan sebagai preambule (pembukaan) undang-undang dasar bagi Negara Indonesia yang akan dibentuk. Dokumen ini ditandatangani oleh sembilan tokoh nasional di Jakarta pada tanggal 22 Juni 1945 Anda Ir. Soekarno, Dr. Mohammad Hatta, Sr.A.A. Maramis, Abikusno Tjokrosujoso, Abdul Kahar Muzakir, H. Agus Salim, Achmad Subardjo, Wahid Hasyim dan Muhammad Yamin. Karenanya, sengkarut peneriapan syariat di Indonesia

\footnotetext{
${ }^{1}$ Bernard Lewis, Islam and The West (New York: The Oxford University Press, 1991), h. 181

${ }^{2}$ Abd. Halim Barakatullah dan Teguh Prasetyo, Hukum Islam Menjawab Tantangan Zaman Yang Terus Berkembang, (Yogyakarta, Pustaka Pelajar, 2015), h.68
} 
menarik untuk dikaji lebih jauh. Dengan menggunakan pendekatan sosial historis (sosiolegal-historis) artikel ini berupaya untuk melacak kekacauan (baca: pro-konta) formalisasi syariat di Indonesia, dan mencoba memberi gambaran seberapa jauh peluang formalisasi syariat ini disetujui.

\section{METODE}

Jenis penelitian ini adalah penelitian kualitatif. ${ }^{3}$ Sedangkan pendekatan yang digunakan adalah sosio-legal-historis. Pendekatan sosiologi, terutama sosiologi hukum digunakan untuk mengamati pola-pola interaksi antara kekuatan-kekuatan politik dan respon politik terhadap formalisasi syariat di Indonesia, baik yang mengilhami formalisasi syariat dan legislasi hukum Islam, maupun menyangkut kesesuaian kesadaran masyarakat muslim dengan produk legislasi hukum Islam dalam dinamika perpolitikan di Indonesia. Pendekatan legal atau yuridis dilakukan dengan mempertimbangkan elemen-elemen tertentu dari hukum Islam (syariat) yang telah dituangkan dalam peraturan perundangundangan di Idonesia yang berlaku dalam sistem hukum nasional, dan secara sosiologis ditelaah situasi sosial yang mengitarinya.

\section{PEMBAHASAN}

\section{Makna dan Watak Syari'ah}

Dalam bahasa, kata "Syara" berarti "datang." Syara 'al-warid berarti memasukkan air ke mulut. Syara'at al-dawabb fi al-ma" berarti bahwa ia memasuki air. Kata-kata al-syari'ah, alsyira' dan masyra'ah berarti tempat air mengalir. Kata Syari'ah dan Syir'ah juga berarti tempat air, sumber air yang darinya manusia dapat mengambil dan minum air. Terkadang sumber air ini juga ditujukan untuk hewan peliharaan mereka. ${ }^{4}$

Kata tasyra sebagai turunan dari kata syari ah juga berarti membawa unta ke tempat air untuk minum sendiri, sehingga gembala tidak harus mengisi minuman untanya dengan seember air. Pepatah Arab mengatakan ahwan al-saqy al-tasyra (cara terbaik untuk minum adalah dengan membawa unta ke suatu tempat air). Pepatah ini berlaku untuk orang yang melakukan sesuatu yang mudah dan tanpa usaha. Tasyra bertujuan untuk membuat hidup lebih mudah atau lebih nyaman. ${ }^{5}$

\footnotetext{
${ }^{3}$ Untuk penjelasan lebih lanjut tentang metode kualitatif lihat Lexy Moeloeng, Penelitian Kualitatif, (Bandung: Rosdakarya, 1995), h. 3.

${ }^{4}$ Ibn Manẓr, Lisan al- 'Arab, (Beirut: Dar al-Kutub al-'ilmiyyah, jilid 5, cet. 1), h. 160

${ }^{5}$ Ibn ManẒr, Lisan al-'Arab, h. 161-162.
} 
Mahmud Syaltut, Syariah, adalah "semua hukum dan aturan yang ditetapkan oleh Allah SWT untuk diikuti oleh para hamba-Nya yang menentukan hubungan antara manusia dan Tuhan, hubungan antara manusia dan manusia, dan hubungan antara manusia dan lingkungan". Sementara itu, Manna Al Qathan mendefinisikan hukum Syariah dengan pemahaman bahwa "semua peraturan Allah ditentukan untuk para hambaNya, baik dalam hal akidah, pujian, moralitas, dan mu'amalah."7 Sementara Muhammad Mustafa Syalabi mengetomologikan bahwa "syariah sebagai suatu rujukan hukum dalam Islam yang diwahyukan kepada Nabi Muhammad, yang direkam dalam Al-Qur'an dan Sunnah Nabi" ${ }^{8}$

\section{Perbedaan Syariah dengan Fiqh}

Syari'ah berbeda dari Fiqh. Syari'ah identik dengan Wahyu, dan pengetahuannya hanya dapat diperoleh dari Al-Quran dan Sunnah. Sedangkan fiqh umumnya dikembangkan oleh para ahli hukum dan terdiri dari aturan-aturan yang didasarkan terutama pada pemikiran manusia dan ijtihad. Cakupan syariah lebih luas pada semua aspek perilaku manusia. Ruang lingkup yurisprudensi lebih sempit, tetapi ini semua berkisar pada hukum praktis (al-ahkam al-amaliyyah). Allah dan Rasul-Nya menggariskan ketetapan Syariah, sedangkan yurisprudensi Fiqh didasarkan pada kerja manusia. Cendekiawan Muslim umumnya mendefinisikan Fiqh sebagai pemahaman tentang Syariah, bukan Syariah itu sendiri. ${ }^{9}$

Hubungan antara Syariah dan Fiqh sangat erat dan tidak dapat dipisahkan. Syariah merupakan sumber atau landasan Fiqh, sedangkan Fiqh merupakan pemahaman terhadap syariah. Pemakaian kedua istilah ini sering rancu, artinya ketika seseorang menggunakan istilah syariah terkadang maksudnya adalah fiqh, dan sebaliknya ketika seseorang menggunakan istilah fiqh terkadang maksudnya adalah syariah. Hanya saja kemungkinan yang kedua ini sangat jarang. Meskipun syariah dan fiqh tidak dapat dipisahkan, keduanya tetap berbeda. Syariah diartikan dengan ketentuan atau aturan yang ditetapkan oleh Allah tentang tingkah laku manusia di dunia dalam mencapai kehidupan yang baik di dunia dan akhirat. Ketentuan syariah terbatas dalam firman Allah dan penjelasannya melalui sabda Rasulullah SAW. Semua tindakan manusia di dunia dalam tujuannya mencapai kehidupan yang baik harus tunduk kepada kehendak Allah Swt. dan Rasulullah Saw. Kehendak Allah dan Rasulullah itu sebagian telah terdapat secara tertulis dalam Alquran dan Sunnah yang disebut syariah, sedang sebagian besar lainnya tersimpan di balik apa yang tertulis itu, atau

\footnotetext{
${ }^{6}$ Mahmud Syaltut, Al-Islam Aqidah wa Syariah, (Beirut : Dar al-Fikr), h. 15

${ }^{7}$ Manna' al-Qathan, al-Tasyri' wa al-Fiqh fi al-Islam, (Muassasahal-Risalah), h. 15.

8 Muhammad Musthafa Syalabi, Al-Madkhal Fi at-Ta'rif bi al-Fiqh al-Islami, (Dar al-Nahdhah alArabiyah, 1969), h 28

${ }^{9}$ Mohammad Hashim Kamali, Shari ah Law: An Introduction, (Oxford: Oneworld, 2008) h. 16
} 
yang tersirat. ${ }^{10}$ Secara umum syariah adalah hukum Islam yang bersumber dari Alquran dan Sunnah yang belum dicampuri daya nalar (ijtihad), sedangkan fikih adalah hukum Islam yang bersumber dari pemahaman terhadap syariah atau pemahaman terhadap nash, baik Alquran maupun Sunnah.

Berdasarkan pemahaman para ahli yang disebutkan di atas, dapat disimpulkan bahwa Syariah adalah sistem aturan berdasarkan ajaran Allah (Al-Qur'an) dan Rasul (Sunnah) dan mencakup semua aspek kehidupan manusia, termasuk hubungan manusia dengan Tuhan dan hubungan manusia dengan manusia dan juga hubungan dengan alam lingkungan mereka.

\section{Hubungan Syariah dan Negara}

\section{Hakekat Negara}

Biasanya, ketika suatu negara didirikan, umumnya orang tersebut hidup dalam lingkungan yang kooperatif dan antagonis dan kontroversial. Untuk alasan ini, dianggap perlu untuk memiliki asosiasi yang menetralkan kondisi antagonis kepada orang lain. Asosiasi ini memiliki wewenang untuk mengatur hubungan sesama manusia dan dapat mengintegrasikan dan bahkan mengarahkan kegiatan-kegiatan sosial penduduk menuju tujuan bersama. Asosiasi ini kemudian disebut Negara. ${ }^{11}$

Negara adalah otoritas komunitas yang memiliki otoritas untuk mengatur, mengatur, dan mengendalikan hubungan di antara mereka. Tujuan akhir yang harus dicapai adalah untuk menciptakan kesejahteraan dan kebahagiaan penduduk atau masyarakat, atau untuk mengatur masyarakat yang adil dan makmur. Setiap negara memiliki organisasi yang diberdayakan untuk merumuskan dan mengimplementasikan keputusan yang mengikat seluruh penduduk di wilayahnya, yang disebut pemerintah. Pemerintah ini bertindak atas nama negara dan menjalankan kekuasaan negara dengan mengambil beberapa arahan dan keputusan dalam berbagai bentuk undang-undang untuk mencapai tujuan bersama. Pemerintahan sering dibagi menjadi kekuatan legislatif, eksekutif dan yudikatif. ${ }^{12}$

Dalam pandangan Islam, manusia di dunia ini adalah agen yang diberi dan menerima perintah Tuhan untuk memelihara dan mempertahankan alam semesta. Untuk memahami konsep ini, Al-Qur'an ${ }^{13}$ menjelaskan perlunya sekelompok orang yang terus mencari kebajikan dan mencegah kejahatan agar tercipta keadilan dan hilangnya tirani. Untuk

${ }^{10}$ Marzuki, "TINJAUAN UMUM TENTANG HUKUM ISLAM", Makalah di Sampaikan pada Seminar PSP Nusantara 2016, h. 10

${ }^{11}$ Miriam Budiardjo, Dasar-Dasar Ilmu Politik, (Jakarta : Gramedia, 1986), h. 38 dan 45

${ }^{12}$ Miriam Budiardjo, Dasar-Dasar Ilmu Politik, h. 44-46

${ }^{13}$ (Al-Quran 3: 103-104) 
mencapai tujuan tersebut, menurut Muhammad Asad, harus ada instrumen yang dapat mengatur pencapaian tujuan tersebut. Instrumen ini biasanya dilakukan di seluruh negeri. Negara dijalankan oleh pemerintah di mana ada seorang imam atau kepala negara. Negara itu sendiri bukan merupakan tujuan tetapi sarana untuk mencapai tujuan. ${ }^{14}$

Menurut Muhammad Asad bahwa tujuan intinya adalah "sebuah perwujudan masyarakat yang selalu mempraktikkan kebajikan dan keadilan, membela kebenaran dan meruntuhkan kepalsuan, yaitu masyarakat yang berupaya menciptakan kondisi sosial yang memberi kemungkinan seluas-lusanya kepada sebanyak mungkin anggota masyarakat untuk hidup sesuai dengan hukum dan standar moral yang yang konsisten sesuai dengan fitrah yang datang dari Allah Swt, baik aspek spiritual maupun material. ${ }^{15}$ Karena hal tersebut maka pendirian sebuah Negara sangat penting, bahkan Muhammad Yusuf Musa mengatakan bahwa dikalangan para Ulama berpendapat tentang dasar atau penunjukan seorang pemimpin adalah wajib. ${ }^{16}$ Menurut al-Mawardi bahwa pemerintah (Khilafah/Imamah) berfungsi sebagai pengganti keudukan Nabi dalam tugas melestarikan agama dan mengatur dunia. ${ }^{17}$

Tujuan dan Fungsi Negara

Tujuan negara yang dinyatakan secara umum adalah untuk menciptakan kemakmuran dan kebahagiaan masyarakat atau rakyat. ${ }^{18}$ Menurut prinsip-prinsip Islam, tujuan negara seperti yang dijelaskan oleh Ibnu Taimiyah, adalah realisasi Syariah (ajaran Islam) di komunitas umat. Sehingga seseorang yang diyakini memiliki kendali atas pemerintah harus menjalankan fungsi negara sesuai dengan tujuan negara.

Pemerintah, yang diberi wewenang untuk merumuskan dan melaksanakan kebijakan, harus menjalankan tugasnya untuk mencapai tujuan masyarakat dengan mengeluarkan berbagai bentuk undang-undang dan peraturan berdasarkan Amar Ma'ruf, yaitu mengikuti prinsip kepemimpinan yang baik (alchhair) dan kemakmuran (al-falah) serta keadilan dan kemakmuran (al-baldah tayyibah). Dan lakukan Nahi Munkar, yang mencegah ketimpangan dan kerusakan (fasad), yang dilambangkan dengan istilah Warabbun Ghafur (pengampunan ilahi). ${ }^{19}$

\footnotetext{
${ }^{14}$ Muhammad Asad, Minhaj al-Islam fi al-Hukmi, terjemahan Indonesia, Sebuah Kajian tentang Sistem Pemerintahan Islam, (Bandung: Pustaka, 1985 ), h. 60

15 Muhammad Asad, Minhaj al-Islam fi al-Hukmi, terjemahan Indonesia, Sebuah Kajian tentang Sistem Pemerintahan Islam, h. 60

${ }^{16}$ Muhammad Yusuf Musa, Nizhamul Hukmi Fil Islam, ( Kairo : Darul Katib al-’ Arabiy, 1965), h. 15-18

${ }^{17}$ Al-Mawardi, al-Ahkam as-Sultaniyyah, (Beirut: Dar al-Fikr, 1981), h. 3

${ }^{18}$ Miriam Budiardjo, Dasar-Dasar Ilmu Politik, h. 45

${ }^{19}$ Dawam Rahardjo, “ Ekonomi Islam, Ekonomi Pancasila dan Pembangunan Ekonomi Indonesia, dalam Ainur R. Sophian (edt), Etika Ekonomi Politik, (Surabaya: Risalah Gusti, 2014), h. 124-125.
} 
Meskipun amar makruf nahi munkar ini pada awalnya bukan merupakan kewajiban individu muslim, yakni kewajiban tersebut bersifat kolektif (fardhu kifayah), namun bisa menjadi kewajiban personal/individual (fardhu 'ain) pada saat tidak ada satupun pihak yang sanggup melaksanakannya. Dalam hal ini, pihak yang memiliki wewenang dan kompetensi, seperti negara, merupakan institusi yang paling bertanggung jawab untuk implementasikannya. ${ }^{20}$ Itu sebabnya negara memiliki peran penting.

Adapun fungsi negara secara umum, menurut Miriam Budiardjo, adalah melaksanakan penertiban (law and order) atau bertindak sebagai "stabilisator"; mengusahakan kesejahteraan dan kemakmuran rakyatnya; menjaga pertahanan (menjaga kemungkinan serangan dari luar); dan menegakkan keadilan.28 Sedangkan menurut Ibn Taimiyah, sedikitnya ada lima bentuk fungsi negara dalam menegakkan amar makruf dan nahi munkar, yaitu

a. Pelaksanaan dasar-dasar agama Islam;

b. Penegakkan hukum/keadilan dan perlindungan hak-hak;

c. Pemeliharaan ketertiban dan keseimbangan ekonomi;

d. Penyediaan infrastruktur sosial; dan

e. Pembelaan keamanan negara. ${ }^{21}$

Bagaimana harusnya wujud undang- undang Negara memiliki esensi amar makruf nahi munkar? Dengan kata lain bagaimana pemerintah bertindak untuk memenuhi tugas dan perannya? Jawabannya tergantung pada kondisi sosial yang ada di masyarakat. Dalam masyarakat Islam, jawaban atas pertanyaan ini idealnya didasarkan pada teori Maslahah. Dimana para ahli menggunakan kata ini untuk menunjukkan kepentingan umum atau kepentingan manusia pada umumnya. ${ }^{22}$

Negara dalam Konsep Modern

Konsep dan praktik negara modern serta konsep demokrasi tidak tunggal. Unsurunsur negara dan demokrasi dipengaruhi, dibentuk dan diperkaya oleh kultur dan struktur yang ada. Dengan kata lain, konsep dan praktik demokrasi modern digerakkan oleh konstruk sosiologis dan budaya masyarakat setempat. ${ }^{23}$ Selanjutnya, dengan mengutip pendapat Rober A. Dahl, Effendi menjelaskan unsur-unsur negara modern yang dianggap sebagai negara demokratis sebagai berikut:

\footnotetext{
${ }^{20}$ Ahmad bin Abdul Halim bin Taimiyah, al-Hisbah fi al-Islam aw Wadhifatu al-Hukumiyah al-Islamiyyah, h. 11

${ }^{21}$ Miriam Budiardjo, Dasar-Dasar Ilmu Politik, h. 46.

${ }^{22}$ Ahmad bin Abdul Halim bin Taimiyah, al-Siyasah al-Syar 'iyyah Fi Ishlahi al-Ra’iy wa al-Ra 'iyyah, (Beirut: Dar al-Jail, 1993), h. 28-130.

${ }^{23}$ Bahtiar Effendi, "Islam dan Demokrasi: Mencari Sebuah Sintesa Yang memungkinkan”, dalam Nasir Tamara (edt), Agama dan Dialog Peradaban, (Jakarta: Paramadina, 1996), h. 88
} 
a. Menyelenggarakan pemilihan yang terbuka dan bebas;

b. Mengembangkan pola kehidupan politik yang kompetitif;

c. Memberi perlindungan terhadap kebebasan masyarakat.

Sedangkan menurut Juan Linz, sebuah politik baru bisa dikatakan demokratis jika:

a. Memberi kebebasan bagi masyarakatnya untuk merumuskan preferensipreferensi politik mereka, melalui jalur-jalur perikatan, informasi, dan komunikasi;

b. Memberikan kesempatan bagi warganya untuk bersaing secara teratur, melalui cara-cara damai; dan

c. Tidak melarang siapapun untuk memperebutkan jabatan-jabatan politik yang ada. ${ }^{24}$

Sedangkan Masykuri Abdillah menyimpulkan bahwa demokrasi mengandung unsurunsur:
a. Kekuasaan mayoritas,
b. Suara rakyat,
c. Pemilihan yang bebas, dan
d. Bertanggung jawab. ${ }^{25}$

Berdasarkan uraian di atas dapat disimpulkan bahwa unsur-unsur pokok negara modern yang demokratis adalah meliputi adanya proses rekrutmen elit melalui pemilihan yang jujur dan bebas; dan hak masyarakat untuk memilih. Pelaksanaan dari konsep demokrasi ini akan menjamin kebebasan untuk berpendapat dan berserikat, adanya pertanggungjawaban pimpinan terhadap warga negara yang memberikan mandat kepadanya, dan menjamin kemasalahan bagi warga negaranya.

\section{Islam dan Sistem Formal Negara Dari Masa Klasik Hingga Modern}

Doktrin politik dalam sistem formal Negara berkembang di dunia Sunni adalah "Khilafah". Ini berbeda dari dunia Syiah, yang mengenal istilah "Imam". Imam al-Mawardi (975 - 1059 M) ahli teori tata negara terkenal, menulis dalam bukunya al-Aḥ̂ām alSulțāniyyah (hukum konstitusional), yang secara eksplisit menjelaskan konsep "Khilafah". Dia berpendapat bahwa mengangkat pemimpin politik (imām) bagi umat dengan peran

\footnotetext{
${ }^{24}$ Bahtiar Effendi, "Islam dan Demokrasi: Mencari Sebuah Sintesa Yang memungkinkan", dalam Nasir Tamara (edt), Agama dan Dialog Peradaban, h.89

${ }^{25}$ Masykuri Abdillah, Islam dan Demokrasi, Respons Intelektual Muslim Indonesia Terhadap Konsep Demokrasi 1966 1993, (Jakarta: Kencana, 2015), h. 71
} 
sebagai "khilāfah al-nubuwwah fi khirāṣah al-dī n wa sìyāsah al-dunyā" (penggantian misi Nabi untuk menjaga agama dan mengatur masalah keduniaan) merupakan sebuah kewajiban. $^{26}$

Dalam bahasa politik yang berbeda, Ibnu Taymiyah (1263-1329 M) melihat hubungan agama (Islam) dengan politik ini secara fungsional. Keberadaan kepemimpinan politik dalam Islam semata-mata sebagai “amanah... an yahkum bi al- 'adP” (amanah untuk menegakkan hukum dengan adil). ${ }^{27}$ Ibnu Taymiyah menyebutkan tentang kewajiban adanya kepemimpinan politik ini disebabkan karena "lā qiyāma li al-d̄ n illā bihā" (tidak akan tegak agama tanpa keberadaan negara). ${ }^{28}$ Untuk mengatur kemaslahatan dunia, maka mau tak mau sebuah negara diperlukan. Untuk memilih pemimpin politik ini, menurut alMawardi, perlu adanya Ahl al-Ikhtiyār. Yakni, semacam lembaga perwakilan yang bertugas untuk menyeleksi calon-calon pemimpin itu (Ahl Imāmah) bagi umat. ${ }^{29}$ Dengan demikian, dalam paradigma politik Sunni sangat ditekankan proses musyawarah (syura) yang diharapkan bisa melahirkan suatu kesepakatan politik (ijmā'). Dalam tradisi politik Sunni, lembaga syura ini lebih dikenal dengan nama Ahl al-Hall wa al-'Aqd.

Dalam berbagai bahasa politik, Ibnu Taimiyah (1263-1329 M) melihat hubungan antara agama (Islam) dan politik secara fungsional. Keberadaan kepemimpinan politik dalam Islam hanya dipahami sebagai “amanah...an yahkum bi al-'adP” (mandat untuk menegakkan hukum yang adil). ${ }^{30}$ Ibnu Taymiyah menyebutkan tentang kewajiban adanya

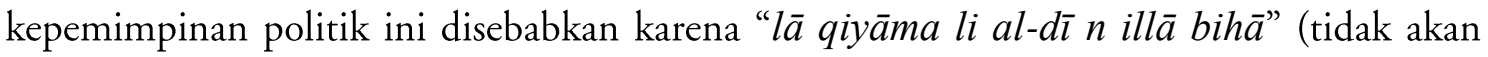
tegak agama tanpa keberadaan negara). ${ }^{31}$ Untuk mengatur kemaslahatan dunia, maka mau tak mau sebuah negara diperlukan. Untuk memilih pemimpin politik ini, menurut alMawardi, perlu adanya Ahl al-Ikhtiyār. Yakni, semacam lembaga perwakilan yang bertugas untuk menyeleksi calon-calon pemimpin itu (Ahl Imāmah) bagi umat. ${ }^{32}$ Dengan demikian, dalam paradigma politik Sunni sangat ditekankan proses musyawarah (syura) yang diharapkan bisa melahirkan suatu kesepakatan politik (ijmā'). Dalam tradisi politik Sunni, lembaga syura ini lebih dikenal sebagai $A h l$ al-Al-wa al-'Aqd.

Tidak cukup dengan ijma' dalam proses syura, yakni, perjanjian politik antara para "wakil rakyat". Tradisi politik Sunni juga menekankan kemestian dalam pengakuan umat Islam (rakyat) terhadap kepemimpinan khalifah atau kepala negara. Pengakuan politis ini

\footnotetext{
${ }^{26}$ Al-Mawardi, al-Ahkam as-Sultaniyyah, h. 3

${ }^{27}$ Ahmad bin Abdul Halim bin Taimiyah, Al-Siyasah al-Syar'iyah, (Beirut: Dar al-Kitabah al-Arabiya, 1966), h. $4 \& 511$

${ }^{28}$ Ahmad bin Abdul Halim bin Taimiyah, Al-Siyasah al-Syar'iyah , h. 139

${ }^{29}$ Al-Mawardi, al-Ahkam al-Sulthaniyyah, h. 5.

${ }^{30}$ Ahmad bin Abdul Halim bin Taimiyah, Al-Siyasah al-Syar'iyah, (Beirut: Dar al-Kitabah al-Arabiya, 1966), h. 4-511

${ }^{31}$ Ahmad bin Abdul Halim bin Taimiyah, Al-Siyasah al-Syar'iyah , h. 139

${ }^{32} \mathrm{Al}-$ Mawardi, al-Ahkam al-Sulthaniyyah, h. 5.
} 
disebut 'al-bay'at'. ${ }^{33}$ Apabila seorang khalifah telah ditetapkan, maka ia pun mesti membay'at umat. Kesediaan umat untuk di-bay'at oleh khalifah menunjukkan 'bentuk' persetujuan politiknya untuk taat dan diperintah oleh yang bersangkutan.

Bahkan di kalangan Syiah, perumusan teori politik Islam tentang administrasi negaran terus berlangsung. Muslim Syiah merumuskan teori "Imamah," yang menyebut Islam sebagai din wa dawlah (agama dan negara). Kemestian bagi seorang imam adalah mendapat predikat—atau sampai pada tingkat iṣmah, yakni kesucian dari dosa. Dalam istilah yang lebih terkenal adalah ma'șüm, terjaga dari dosa; suatu kategori yang dipercayai hanya bisa dimiliki oleh para keturunan Nabi (ahl bayt dari garis Ali). ${ }^{34}$ Konsep ișmah inilah yang merupakan sumber legitimasi untuk menjadi seorang imam, yang mengarah ke agama dan pada saat yang sama dengan negara.

Perubahan konsep politik Islam disebabkan oleh pendudukan dunia Islam oleh negara-negara Barat. Pengaruh pemikiran Barat mau tidak mau termasuk dalam kehidupan politik umat Islam. Ilustrasi cantik tentang kenyataan itu disampaikan oleh Basam Tibi, "for the term 'Islamic Republic' in either Sunni or shi'ite Muslim sources is a new invention documenting European influences on Islam" (untuk istilah 'Republik Islam' dalam literatur Muslim Sunni atau Syiah adalah penemuan baru yang mendokumentasikan pengaruh Eropa pada Islam). Sebab, kata Tibi, Konsep "republik" berasal dari Barat, bukan konsep Islam. Sebelum pengaruh Barat, kaum Sunni hanya mengetahui sistem kekhalifahan, sementara kaum Syiah hanya tahu sistem Imamah. ${ }^{35}$ Masuknya konsep politik Barat menyebabkan perdebatan dikalangan umat Islam tentang konsep klasik dengan kekhalifahan dan dengan konsep negara-bangsa dengan demokrasi. Ketegangan ini tampak dari perdebatan yang hingga saat ini belum selesai.

Sedangkan sistem formal Negara Indonesia dengan mayoritas penduduknya beragama Islam adalah negara bangsa dengan sistem demokrasi yang berideologikan Pancasila. Menurut Mohammad Natsir, Islam dan negara tidak dapat dipisahkan, tetapi masalahnya adalah bahwa di Indonesia ada beberapa ras dan agama yang bukan hanya Muslim. Islam hanya agama mayoritas di Indonesia. Sehingga pemerintahan yang dibentuk jika dengan negara Islam dinilai tidak adil dengan agama yang lain, padahal Indonesia adalah negara demokrasi yang sangat menjunjung keadilan bagi warga negaranya sebagaimana sila kelima Keadilan sosial bagi seluruh rakyat Indonesia. ${ }^{36}$

\footnotetext{
${ }^{33}$ Tentang bay'at sebagai doktrin politik, lihat Fathi Osman. "Bay'ah al-Imam: Kesepakatan Pengangkatan Kepala Negara Islam,” dalam Mumtaz Ahmad (ed.). Masalah-Masalah Teori Politik Islam (Bandung: Mizan, 1993), h. 75-116.

${ }^{34}$ Munawir Sjadzali, Islam dan Tata Negara (Jakarta: UI press, 1991), h. 211-212.

${ }^{35}$ Bassam Tibi, Islam and a Cultural Accomodation in Social Change (Bouldier: Westview Press, 1990), h. 161 162.

${ }^{36}$ Muhammad Natsir, Capita Selekta, (Jakarta: Bulan Bintang, 1954) h. 436
} 


\section{Pancasila Sebagai Ideologi Negara}

Ideologi memainkan peranan yang penting dalam proses dan memeliara integrasi nasiona, terutama di Negara-negara yang sedang berkembang seperti Indonesia. Istilah ideologi berasal dari kata 'idea' berarti gagasan, konsep, pengertian dasar, cita-cita, dan 'logos' berarti ilmu. Kata idea sendiri berasal dari bahasa Yunani 'eidos' yang artinya bentuk. Selanjutnya ada kata 'idein' yang artinya melihat. Dengan demikian secara harfiah ideologi berarti ilmu pengertian-pengertian dasar, cita-cita yang bersifat tetap yang harus dicapai, dan sekaligus merupakan dasar, pandangan atau faham. Kaelan menyatakan bahwa ideologi sebagai pandangan masyarakat memiliki karakteristik: 1) ideologi sering muncul dan berkembang alam situasi kritis; 2) ideologi memiliki jangkauan yang luas, beragam, dan terprogram; 3) ideologi mencakup beberapa strata pemikiran dan panutan; 4) ideologi memiliki pola pemikiran yang sistematis; 5) ideologi cenderung eksklusif, absolute dan universal; 6) ideologi memiliki sifat empiris dan normatif; 7) ideologi dapat dioperasionalkan dan didokumentasikan konseptualisasinya; (h) ideologi bisanya terjadi dalam gerakangerakan politik. ${ }^{37}$

Sebagai suatu ideologi bangsa dan Negara Indonesia maka Pancasila pada hakikatnya bukan hanya merupakan suatu hasil perenungan atau pemikiran seseorang atau kelompok orang sebagaimana idelogi-ideologi lain di dunia, namun Pancasila diangkat dari nilai-nilai adat-istiadat, nilai-nilai kebudayaan serta nilai religius yang terdapat dalam pandangan hidup masyarakat Indonesia sebelum membentuk Negara, dengan lain perkatan unsurunsur yang merupakan materi (bahan) Pancasila tidak lain diangkat dari pandangan hidup masyarakat Indonesia sendiri, sehingga bangsa ini merupakan kausa materialis (asal bahan) Pancasila. Ideologi berkaitan dengan tertib sosial, dan tertib politik yang ada, berupaya untuk secara sadar sisteatis mengubah, mempertahankan tertib masyarakat. Suatu pemikiran mendalam, menyeluruh, menjadi ideologi apabila pemikiran, gagasangagasan tersebut secara praktis difungsikan ke dalam lembaga-lembaga politik suatu masyarakat, suatu bangsa, suatu Negara. ${ }^{38}$

Pancasila diterima oleh seluruh lapisan bangsa, dan tidak ada lagi yang dipertentangankan mengenai nilai-nilai Pancasila dengan agama manapun, termasuk Islam. Penerimaan ini memerlukan waktu yang tidak sebentar. ${ }^{39}$ Pada awalnya panitia Sembilan menyepakati naska Mukadimah UUD 45 yang dikenal dengan piagam Jakarta pada tanggal

37 Ambiro Puji Asmaroini, "Menjaga Eksistensi Pancasila Dan Penerapannya Bagi Masyarakat Di Era Globalisasi,” JPK: Jurnal Pancasila dan Kewarganegaraan, Vol. 2, No. 1, Januari 2017 E-ISSN 2527-7057, P-ISSN 2545-2683, h. 54

38 Ambiro Puji Asmaroini, "Menjaga Eksistensi Pancasila Dan Penerapannya Bagi Masyarakat Di Era Globalisasi," h. 55

${ }^{39}$ Ahmad Syafi'I Ma'arif, "Strategi Pelambangan Nilai-NIlai Pancasila dalam Perspektif Agama, Sosial dan Budaya”. Dalam tim penyusunan Studi Pancasila UGM dan Universitas Patimura Ambon, Prosiding kongres Pancasila VI: Penguatan, Singkronisasi, Harmonisasi, Memperkokoh Kedaulatan Bangsa, (Yogyakarta: PSP UGM, 2014), h. 43 
22 Juni $1945 .^{40}$ Namun kesepakatan itu berubah kerena adanya keberaran dari kalangan minoritas terhadap piagam Jakarta. ${ }^{41}$ Saat ini, Pancasila, sebagai dasar Negara, memiliki posisi penting dalam kehidupan berbangsa dan bernegara. Sebab Negara yang merupakan institusi utama pengaturan masyarakat, tidak hanya mengatur aspek material tetapi juga mental. Dengan mendasarai Negara sebagai nilai-nilai normative, Pancasila juga semestinya menjadi pola dasar dari cara berfikir dan bertindak dalam bermasyarakat. ${ }^{42}$

Menurut Mahfud MD, Pancasila adalah sebagai fitrah bangsa Indonesia. Pancasila tidak bias digantikan dengan ideology lain. Karena Pancasila digali dari budaya bangsa yang sudah berakar selama berabad-abad dan dipraktikkan oleh nenek moyang bangsa Indonesia. Pancasila juga menjadi cara hidup bagi bangsa, sehingga Mahfud MD menyebutnya sebagai jiwa bangsa. Pancasila yang menyatukan suku bangsa yang beragam di Indonesia. ${ }^{43}$

\section{Formalisasi Syariah Di Indonesia}

Ide formalisasi syariat Islam di Indonesia sudah muncul sejak sesaat setelah bangsa Indonesia menyatakan kemerdekaanya. $\mathrm{Hal}$ ini bisa dilihat dari proses perumusan dasar Negara Kesatuan Republik Indonesia, sampai pada masa Orde Lama. Meski pada era Orde Baru isu ini tidak begitu menjadi sorotan media, namun sesaat setelah kejatuhannya (era reformasi) isu ini kembali muncul ke publik. Logika mayoritas (Muslim) selalu menjadi dalih bagi kelompok pengusung ide formalisasi syariat untuk mendorong penerapan hukum Islam secara legal formal. Tetapi adalah fakta bahwa kemerdekaan Indonesia bukan hanya diperjuangkan oleh orang Islam. Formalisasi syariat tentu memiliki konsekuensi. Selain faktor politik, sejarah, sosiologis, dan antropoligis, masa depan bangsa Indonesia pun menjadi taruhannya. ${ }^{44}$

Pancasila konteks kedudukan syariah di dalam sistem ketatanegaraan di Indonesia, pelaksanaan hukum agama (syariah Islam) sering kali menjadi perdebatan yang berlanjut, baik ketika masa persiapan kemerdekaan dengan adanya Piagam Jakarta, bahkan sampai saat ini. Polemik tersebut tidak hanya berkutat pada perkara teknis juridis. Ia menyentuh perkara politik yang sangat peka, terkait hubungan formal antara agama di satu pihak

\footnotetext{
${ }^{40}$ Ni'matul Huda dkk, Teori dan Hukum Konstitusi, (Jakarta: Rajawali Press, 2014), h. 85.

${ }^{41}$ Syamsuddin Haris, Masalah-Masalah Demokrasi dan Kebagsaan Era Reformasi, (Jakarta: Yayasan Pustaka Obor Indonesia, 2015), h. 161

${ }^{42}$ Ahmad Suhendra, Penguatan Nilai-Nilai Kebangsaan dan Pancasila dalam Menangkal Benih Radikalisme di Kalangan Pelajar Tangerang, (Tangerang: PSP Nusantara Press, 2018), h. 54

${ }^{43}$ Moh Mahfud MD, "Ceramah Kunci Ketua Mahkamah Konstitusi” Dalam tim Penyusunan Studi Pancasila UGM dan Universitas Patimura Ambon, Prosiding kongres Pancasila VI: Penguatan, Singkronisasi, Harmonisasi, Memperkokoh Kedaulatan Bangsa, (Yogyakarta: PSP UGM, 2014), h. 43

${ }^{44}$ Lufaefi, Rekonstruksi Jargon Formalisasi Syariat: Upaya Menjaga Persatuan Dalam Bingkai Keberagaman. Al-A'raf: Jurnal Pemikiran Islam - Vol. XIV, No. 1, Januari - Juni 2017, h 74
} 
dengan negara di pihak lain. Modus Vivendi di Negara Indonesia adalah dengan disepakatinya negara berdasar pada Pancasila sebagai jalan tengah antara aspirasi yang menginginakn negara agama versus negara sekuler. Sejarah menunjukkan, solusi dari tarik menarik ini menyuguhkan modus vivendi yang menarik, yakni sektor publik diurus oleh negara dan sektor privat diberikan kepada agama. Dalam konteks ini, logika hukumnya seperti yang dijelaskan oleh Yusril Ihza Mahendra:

Mengingat Indonesia adalah negara dengan penduduk yang majemuk, maka dalam hal hukum keluarga dan kewarisan, maka hukum Islam itu tetaplah dinyatakan sebagai hukum yang berlaku. Sebagaimana juga halnya, jika ada pemeluk agama lain yang mempunyai hukum sendiri di bidang itu, biarkanlah hukum agama mereka itu yang berlaku. Terhadap hal-hal yang berkaitan dengan hukum perdata lainnya, seperti hukum perbankan dan asuransi, negara dapat pula mentransformasikan kaidah-kaidah hukum Islam di bidang itu dan menjadikannya sebagai bagian dari hukum nasional kita. Sementara dalam hal hukum publik, yang syariat Islam itu sendiri hanya memberikan aturan-aturan pokok, atau asas-asasnya saja, maka biarkanlah ia menjadi sumber hukum dalam merumuskan kaidah-kaidah hukum nasional. ${ }^{45}$

Di era reformasi, dalam amandemen UU 1945 pada tahun 1999, 2000, 2001 dan 2002, muncul kembali aspirasi sebagian kelompok Islam untuk memberlakukan Piagam Jakarta atau syariat Islam secara keseluruhan. Namun aspirasi itu tidak didukung oleh mayoritas anggota MPR dalam pembahasan amandemen UUD 1945, terutama pasal 29. Bahkan ormas-ormas besar seperti Nahdlatul Ulama (NU) dan Muhammadiyah pun tidak setuju dengan apirasi itu. Apirasi itu dianggap dapat menimbulkan perdebatan yang berkepanjangan, yang bisa menimbulkan perselisihan dan konflik antara pendukung dan penentang pelakanaan syariat Islam secara keseluruhan, dan pada ujungnya bisa menjadi ancaman bagi integrasi nasional.

Menurut Masykuri Abdullah, ${ }^{46}$ penerapan hukum Islam di Indonesia termasuk model hubungan interseksional, sebab dalam konteks hukum nasional dilakukan dengan tiga bentuk, yakni:

1. Pelaksanaan syariah secara formal

Yakni untuk hukum-hukum privat tertentu, seperti hukum keluarga, zakat dan haji yang pada saat ini sudah ada Undang-undangnya (UU), serta wakaf dan perbankan syariah;

45 Yusril Ihza Mahendra, "Hukum Islam Dan Pengaruhnya Terhadap Hukum Nasional Indonesia," www.yusril.ihzamahendra.com, diakses pada 10 Oktober 2018.

46 Masykuri Abdilah, "Hubungan Agama Dan Negara Dalam Konteks Modernisasi Politik Di Era Reformasi”. Jurnal Ahkam, Vol. XIII No. 2 (Juli 2013). 
2. Pelaksanaan syari'ah secara substantif

Yakni untuk hukum-hukum privat selain yang telah disebutkan di atas yang besarnya sebenarnya sudah sesuai dengan substansi atau materi hukum Islam, dan hukum publik yang sebagiannya juga sudah sesuai dengan substansi hukum Islam, seperti hukuman mati bagi tindak pidana pembunuhan yang secara meteriil sama dengan qișāṣ; dan

3. Pelaksanaan syariah secara esensial

Jika pelaksanaan secara substantif sulit diwujudkan dalam konteks masa kini, misalnya hukuman penjara bagi tindak pidana pencurian, yang secara esensial sudah sesuai dengan hukum Islam, yakni bahwa pencurian merupakan tindak kejahatan yang harus dikenakan sanksi. Pelaksanaan secara esensial ini dilakukan dengan memahami filosofi atau prinsip-prinsip syariah, yang meliputi tujuan hukum Islam (maqāșid al-Syart' 'ah) dan rahasia yang terdapat dalam suatu hukum tertentu (asrār al-tasyrī̄).

Pada satu sisi, terbitnya UU terkait zakat, wakaf, haji dan perbanka syariah merupakan perwujudan penerimaan sistem hukum Indonesia terhadap pemberlakuan hukum Islam sebagai bagian integral dari hukum nasional. Kondisi ini sepenuhnya merupakan respon reformasi dalam sistem hukum di Indonesia sebagai bagaian integral dari gerakan reformasi politik. Dengan kata lain, demokratisasi dalam sistem hukum di Indonesia.

Di sisi lain, pelaksanaan syariah secara substanstif atau esensial diupayakan melalui integrasi atau penyerapan prinsip-prinsip hukum Islam ke dalam hukum nasional atau kebijakan publik (public policy) secara umum. Pada prinsipnya peraturan hukum yang baik dalam sebuah negara adalah peraturan yang dapat diterima oleh seluruh pihak, dan bukan hanya karena terpaksa mengikuti kelompok mayoritas.

Dengan demikian, berbeda dengan bentuk pelaksanaan yang pertama yang hanya khusus umat Islam, bentuk pelaksanaan kedua dan ketiga menjadikan hukum Islam terintegrasiatau terserap ke dalam hukum nasional yang notebene menjadi peraturan hukum bagi seluruh rakyat. Sebagaimana ditegaskan Nadirsyah Hosen, pengalaman Indonesia dalam mempraktikan pendekatan substantif syari'ah, berdampak positif: "under this approach, the flexibility of Islamic law is secured, and the citizen constitutional rights are guaranteed...the compatibility of shari'a and constitutionalism does not lead to a political chaos upon society. Instid, it protects maslahah al-ammah as the main object of shari'a".

\footnotetext{
${ }^{47}$ Nadirsyah Hosen, Shari'a and Constitutional Reform in Indonesia (Singapore: ISEAS, 2007), h. 233.
} 
Sebagian tokoh Muslim Indonesia, M. Amien Rais dan Hadimulyo misalnya, berpendapat bahwa Pancasila sesungguhnya adalah suatu ideologi Islam atau doktrin kenegaraan Islam versi Indonesia, dan empat pilar Negara -Pancasila, UUD 1945, NKRI dan Bhinneka Tunggal Ika - adalah konsensus kebangsaan yang final. Saiful Arif menutif pendapat Abdurahman Wahid tentang Islam dan Pancasila merujuk pada hubungan antara Islam kebudayaan dan Islam kebangsaan. Islam kebudayaan merujuk pada corak kultural Islam Nusantara, yang menjadi trade mark bagi keislaman Nahdlatul Ulama (NU). Keislaman Keindonesiaan ini yang menjadi bantalan keagamaan bgi hubungan harmonis antara Islam, Pancasila dan Demokrasi. Memahami konsep keislaman pancasialis ala Gus Dur menjadi penting di tengah gerakan Islam yang menolak pancasila. ${ }^{48}$

Namun selama reformasi isu mengenai Negara Islam terus menguat. kehadiran wacana dan gerakan Negara Islam Indonesia (NII) sebagai aksi ideologi-politik bawah tanah, menimbulkan kesan kuat bahwa kontroversi gagasan Negara Islam versus Negara Pancasila belum selesai. ${ }^{49}$ Secara formal politis mungkin masalah ini dapat dianggap selesai, akan tetapi diskursus dan pemikiran tentang hal ini ternyata belum usai. Cita-cita mendirikan dan menegakkan Negara Islam di Indonesia masih tetap hidup dan diperjuangkan oleh kelompok-kelompok semisal NII maupun secara terang-terangan oleh organisasi politik resmi, seperti Hizbut Tahrir Indonesia (HTI), Majelis Mujahidin Indonesia (MMI), Jamaah Anshorut Tauhid (JAT).

Majelis Mujahidin Indonesia (MMI) memiliki ciri khas dalam misi islamisasinya. Ia tidak memiliki agenda untuk merevolusi hukum dan sistem yang telah ada, tetapi menjadikan demokrasi sebagai alat untuk memenangkan perjuangan formalisasi syariat Islam. ${ }^{50}$ Sementara HTI memiliki pandangan tentang islamisasi secara total. Islam harus diterapkan secara keseluruhan, tanpa mempedulikan demokrasi. HTI menginginkan dihapusnya sistem demokrasi dan menggantinya dengan sistem hukum Islam. ${ }^{51}$ Misi HTI memiliki kesamaan dengan kelompok Salafi mengenai pemurnian Islam di seluruh sendi kehidupan bangsa Indonesia. Bagi kelompok ini, bid'ah adalah adalah praktek yang harus dihilangkan dari kehidupan umat Islam karena tidak ada di zaman Nabi. Berbeda dengan HTI, kelompok Salafi tidak bermain dalam peta perpolitikan negara. Gerakan kelompok-

\footnotetext{
${ }^{48}$ Saiful Arif, Islam, Pancasila dan Deradikalisasi: Meneguhkan Nilai Keidonesiaan, (Jakarta: Elex Media Komputindo, 2018), h 8.

${ }^{49}$ Dawam Raharjo, “Kritik Nalar Negara Islam” Islamlib.com. diakses tanggal 10 Oktober 2018

${ }^{50}$ Rio Sulaiman, "Pemikiran dan Kiprah Majelis Mujahidin Indonesia" (UIN Syarif hidayatullah, Jakarta, 2016), h 47

${ }^{51}$ Taqiyuddin An-Nabhani, Nizham Al-Hukm (Beirut: Hizbut Tahrir, 2002), h. 131.
} 
kelompok sejenis ini, di era pasca reformasi tidak hanya dilakukan di level nasional, tetapi juga merambah ke ranah lokal, dengan mengusung isu Perda Syariah. ${ }^{52}$

Alhasil umat Islam yang kontribusinya terhadap berdirinya Negara-bangsa Indonesia dan lahirnya dasar Negara Pancasila ini tidak dapat diragukan lagi sedang dan masih mengalami krisis kepercayaan. kelompok-kelompok ekstrem yang jumlahnya minoritas bahkan menyebut Pancasila dan tiga pilar lainnya -UUD 1945, NKRI dan Bhinneka Tunggal Ika—sebagai ideology "taghut” yang harus dimusnahkan. Krisis pemahaman dan pemaknaan yang hidup atas Pancasila - baik sebagai ideologi maupun konsep Negarayang berujung pada penolakan merupakan persoalan serius yang mesti dijawab oleh bangsa Indonesia, dan umat Islam khususnya. Tulisan ini bermaksud untuk mengemukakan alternatif pemaknaan mengenai konsep negara dalam bingkai Islam dan bingkai Pancasila; dan mengemukakan suatu formula baru memahami "negara syariah" sesuai dengan konteks keindonesiaan. Kajian ini juga secara praktis bisa menjadi tawaran untuk membumikan visi profetik yang lugas dan cerdas dari Pancasila sebagai jalan keluar dari kegamangan dan krisis kepercayaan sebagian umat Islam di negeri ini.

\section{Pro dan Kontra Formalisasi Syariat}

Formalisasi syariat Islam yang cukup gencar tersebut telah menimbulkan pro dan kontra. Salah satu pandangan berusaha mementahkan ajakan formalisasi syariat Islam. Penolakan formalisasi syariah ini diungkapkan dengan berbagai argumentasi dan dalil. Misalnya, ada yang mengatakan bahwa Indonesia adalah masyarakat plural, tidak hanya muslim, maka formalisasi syariat Islam yang berlaku umum tidak dapat diterima. Bahkan ada yang mempertanyakan, kalau mau memformalisasikan syariat Islam, syariat Islam yang mana? Bukankah varian pemahaman umat Islam Islam tentang syariat Islam sifat beragam tidak tunggal? Ada pula yang menyatakan bahwa formalisasi syariat Islam berarti intervensi negara terhadap kehidupan beragama yang seharusnya bersifat privat dan individual. Ada pula yang menolak formalisasi syariat Islam karena syariat Islam tidak sesuai dengan modernitas dan kehidupan publik, misalnya Hukum Internasional, Hak-Hak Asasi Manusia, Demokrasi, dan sebagainya? ${ }^{53}$

Dalam kaitannya dengan itu, Presiden Soekarno pernah menyatakan bahwa jika sebagian besar orang Indonesia benar-benar Muslim dan jika benar bahwa Islam merupakan agama yang hidup di hati rakyat, maka silahkan setiap pemimpin

\footnotetext{
${ }^{52} \mathrm{~N}$ Kafid, "Dari Islamisme ke 'Premanisme ': Pergeseran Orientasi Gerakan Kelompok Islam Radikal di Era Desentralisasi Demokrasi 1,” MASYARAKAT: Jurnal Sosiologi 21, no. 1 (2016): 57-79, http://journal.ui.ac.id/index.php/mjs/article/view/4737.

${ }^{53}$ Adhian Husaini dan Nuim Hidayat. Islam Liberal: Sejarah, Konsepsi, Penyimpangan, dan Jawabannya. (Jakarta: Gema Insani Press), h.155-167.
} 
menggerakkan orang-orangnya agar delegasi muslim menempati kursi parlemen. Dengan demikian undang-undang yang dikeluarkan oleh lembaga perwakilan rakyat ini dengan sendirinya akan menjadi Islami. Begitu juga sebaliknya, bahwa jika orang Kristen, misalnya, menginginkan agar setiap kata-kata dalam peraturan Negara Indonesia sejalan dengan Bible, maka silahkan mereka bekerja dengan sungguh-sungguh agar sebagian besar delegasi yang menduduki badan perwakilan rakyat di Indonesia adalah orang-orang Kristen. ${ }^{54}$

Pernyataan yang dikatakan oleh Soekarno tersebut mengandung pengertian bahwa meskipun jaminan konstitusi untuk menjalankan syari'at Islam gagal diperoleh oleh partai Islam, kesempatan untuk membuat undang-undang atau aturan yang berdasar atau diilhami oleh syari'at Islam melalui mekanisme demokrasi perwakilan di Indonesia masih tetap terbuka luas akan tetapi, itu semua bukan berarti tanpa tantangan yang harus dihadapi. Tantangan tersebut tampak dalam tulisan beberapa pengamat yang khawatir bahwa aktifis Islam akan menggunakan demokrasi untuk mematikan demokrasi. ${ }^{55}$ Bahkan Wendy Asbeek Brusse dan Jan Schoonenboom menyatakan bahwa regim-regim di Timur Tengah serta pendukungnya di Barat enggan memberikan keleluasaan bagi politik Islam untuk bergerak dan berpartisipasi secara penuh dalam pemilihan nasional dan pemilihan parlemen karena mereka beralasan bahwa bila gerakan itu mendapat akses ke politik dan memegang kekuasaan maka mereka akan segera mengakhiri kompetisi demokrasi. Hal ini karena mereka pada dasarnya menolak prinsip demokrasi dan hak asasi manusia yang mereka pandang bertentangan dengan syari'at dan kedaulatan mutlak Tuhan. ${ }^{56}$ Bahkan Ralf Dahrendorf menuliskan bahwa, anggota the British House of Lord dan mantan rector London School of Economics, juga menulis sebagai berikut: the return of religion to politics - and to public life in general - is a serious challenge to the rule of democratically enacted law and the civil liberties that go with it. ${ }^{57}$

Pada masa reformasi, perdebatan soal formalisasi syariat Islam ${ }^{58}$ di Indonesia kembali setelah dua partai Islam, PPP dan PBB mengusulkan dikembalikannya Piagam Jakarta ke

${ }^{54}$ Kamaruzzaman Bustamam Ahmad, Wajah Baru Islam Indonesia, (UII Press, Yogyakarta, 2004), h. 174 -

55 J.Soedjati Djiwandono, Misinterpreted Democracy may Lead to Tyranny, The Jakarta Post, Okt.6,

2006.

${ }^{56}$ Wendy Asbeek Brusse dan Jan Schoonebom, Islamic Activism and Democratization, dalam ISIM (International Institute For The Study Of Islam In The Modern World) REVIEW 18, 2006

${ }^{57}$ Ralf Dahrendorf, Is secularism coming to an end?, The Jakarta Post, November 15, 2006.

${ }^{58}$ Pengertian Syariat Islam sering disamakan dengan pengertian fiqh dan hukum Islam. Ketiganya memang sama-sama merupakan jalan yang berasal dari Allah, tetapi dari perkembangan sejarah Islam, ketiganya telah mengalami diferensiasi makna, Rifyal Ka'bah, "Islamic Law" dalam majalah triwulan Muslim Executive \& Expatriate. Jakarta, Muharram 1, 1420 H, h.19. Syariat Islam secara umum adalah keseluruhan teks Al-Quran dan as-Sunnah sebagai ketentuan Allah yang seharusnya menjadi pegangan manusia atau the right way of Religion, Abdullah Yusuf Ali, The Holy Al-Quran: Text, Translation and Commentary (Brenwood: Maryland Amana Corporation 1989), h.1297. Syariat Islam sampai saat ini sebenarnya mempunyai tiga pengertian. Pertama, sebagai keseluruhan agama yang dibawa oleh Nabi Muhammad saw. Kedua, keseluruhan teks-teks al-Quran dan Sunnah yang merupakan nilai-nilai hukum yang berasal dari wahyu Allah. Ketiga, pemahaman para ahli 
dalam amandemen UUD 1945. Lebih dari itu, sejumlah Ormas Islam- minus Nahdlatul Ulama dan Muhammadiyah-menyuarakan aksi tuntutan kembalinya Piagam Jakarta, yang berarti pula formalisasi syariat Islam di tanah air. Semua ini menunjukkan betapa seriusnya sosialisasi formalisasi syariat Islam yang dilakukan oleh sejumlah kelompok Islam. Sementara di sisi lain, ada kelompok Islam yang menolak formalisasi syariat Islam. Biasanya mereka ini adalah kelompok yang selama ini getol menggagas pluralisme, inklusivisme, toleransi, dan kulturalisasi Islam. Tak berlebihan jika kelompok Islam ini secara tegas justru menginginkan deformalisasi syariat Islam. Syariat Islam secara formal tidaklah perlu. Karena yang menjadi poin mendasar keber-islaman di Indonesia adalah komitmen kepada agama secara substansialistik, bukan legalistik-formalistik, termasuk di dalamnya acuan syariat agamanya. ${ }^{59}$

Prof. Dr. Masykuri Abdillah ${ }^{60}$ menegaskan sikap penolakan NU terhadap formalisasi syariat Islam tidak sepenuhnya benar. NU, menurutnya, tidak menolak formalisasi atau pemberlakuan hukum Islam dalam hukum positif nasional. Namun, formalisasi itu tetap dalam batas-batas yang berkaitan dengan wilayah privat, tidak pada wilayah publik. "Kalau kita dengar, NU menolak semua bentuk formalisasi syariat Islam, kurang tepat. Buktinya NU menerima undang-undang perkawinan, undang-undang haji, dan sebagainya. Kalau NU menolak sepenuhnya formalisasi syariat Islam, berarti NU juga menolak keberadaan departemen agama," terang Masykuri saat hadir sebagai narasumber pada Temu Wicara Pendidikan Kesadaran Berkonstitusi, di Hotel Grand Cempaka, Jakarta, Sabtu (24/2).

Demikian pula sikap NU terhadap maraknya sejumlah peraturan daerah (perda) bernuansa Islam di beberapa daerah di Indonesia. Menurutnya, secara umum perda-perda tersebut tidak bertentangan dengan Undang-undang Dasar. "Perda-perda itu untuk memperjelas peraturan-peraturan yang ada di KUHP (Kitab Undang-undang Hukum Pidana-Red). Walaupun ada beberapa yang memerlukan revisi," tandasnya.

Namun demikian, Masykuri kembali menegaskan bahwa sikap tersebut bukan berarti NU telah berubah haluan dan berkeinginan menjadikan Indonesia sebagai negara Islam. Menurutnya, sikap tersebut merupakan bagian dari sikap NU yang tetap mendukung pelaksanaan syariat Islam secara substansial dan dalam wilayah Negara Kesatuan Republik Indonesia. $^{61}$

${ }^{59}$ Burhanuddin (editor), Syariat Islam Pandangan Muslim Liberal. (Jakarta: Jaringan Islam Liberal dan The Asia Foundation); Charles Kurzman (editor). 2001. Wacana Islam Liberal Pemikiran Islam Kontemporer dan Isu-Isu Global, terjemahan Bahrul Ulum dari Liberal Islam: A Sourcebook. (Jakarta: Paramadina, Yayasan Adikarya IKAPI dan The Ford Foundation, 2003), h.xi-lx

${ }^{60}$ Rais Syuriah PBNU 2015-2020

${ }^{61}$ Masykuri Abdillah, NU Tidak Menolak Formalisasi Syariat Islam, http://www.nu.or.id/post/read/8263/nu-tidak-menolak-formalisasi-syariat-islam. diakses tanggal 19 Oktober 2018. 
Pemikiran deformalisasi di atas didasarkan pada kenyataan riil, syariat sudah terakomodasi secara formal, seperti Undang-undang Perkawinan, Undang-undang Zakat, Undang-undang Haji, Kompilasi Hukum Islam (KHI), dan sejumlah produk perundangundangan lainnya. Syariat Islam pun sudah dipraktekkan umat Islam, seperti salat, zakat, dan haji, tanpa perlu diperintah oleh negara. Kenapa Islam harus mendapatkan legitimasi formal negara? Bukankah ini wujud dari politisasi syariat agama yang cenderung tidak produktif, dan justru menambah deretan konflik? Indonesia ini bukanlah negara agama atau tegasnya bukan negara Islam, sehingga tidak layak memberlakukan syariat Islam secara formal dan total. Indonesia adalah negara plural yang menampung banyak agama, tidak hanya Islam. Sehingga produk perundang-undangannya tidak boleh eksklusif secara keseluruhan, tetapi menampung aspirasi agama-agama lain. Belum lagi problem mendasar dalam memahami syariat Islam. Perbedaan mazhab fiqh akan banyak menimbulkan perbedaan hukum. Inilah yang menyebabkan gagasan formalisasi syariat Islam tidak tepat dan a-historis di bumi nusantara ini.

Sedikitnya, ada tiga arus besar yang mengemuka dalam menyikapi formalisasi syariat Islam. Pertama, arus formalisasi syariat. ${ }^{62}$ Kelompok ini menghendaki agar syariat Islam dijadikan landasan riil berbangsa dan bernegara. Pencantuman kembali Piagam Jakarta dalam UUD 1945 menjadi salah satu target utamanya. Kedua, arus deformalisasi syariat. ${ }^{63}$ Kelompok ini memilih pemaknaan syariat secara substantif. Pemaknaan syariat tidak sertamerta dihegemoni negara, karena wataknya yang represif. Syariat secara individu sudah diterapkan, sehingga formalisasi dalam UUD 1954 tidak mempunyai alasan kuat dalam ranah politik. Ketiga, arus moderat. ${ }^{64}$ Kelompok ini dikesankan mengambil jalan tengah:

${ }^{62}$ Arus ini secara politis dinakhodai oleh oleh partai-partai Islam yang berlandaskan Islam, seperti PPP, PK(S). Selain itu didukung oleh kelompok-kelompok radikal yang mulai tampil ke permukaan, seperti Front Pembela Islam (FPI), KISDI, Hisbut Tahrir, dan beberapa organisasi kepemudaan dan kemahasiswaan. baca Zuhairi Misrawi," Dekonstruksi Syariat; Jalan Menuju Desakralisasi, Reinterpretasi dan Depolitisasi” dalam Tashwirul Afkar Jurnal Refleksi Pemikiran Keagamaan \& Kebudayaan tema Deformalisasi Syariat Islam, edisi No.12 Tahun 2002 (Jakarta: Lembaga Kajian dan Pengembangan Sumberdaya Manusia NU dan The Asia Foundation), h.7. baca juga Irfan Suryahardi Awwas, "Menerapkan Piagam Cerdas" dalam Kurniawan Zein dan Sarifuddin (editor). 2001. Syariat Yes Syariat No Dilemma Piagam Jakarta dalam Amandemen UU 1945. (Jakarta: Paramadina), h.33-35.

${ }^{63}$ Arus ini memang kelihatan tidak segigih kelompok pertama dalam mensosialisasikan gagasannya, tetapi bukan berarti tidak mempunyai basis akar rumput. NU dan Muhammadiyah termasuk organisasi keagamaan dan kemasyarakatan yang berada di garda depan mengkampanyekan deformalisasi syariat. Karena setiap individu muslim dapat melaksanakan syariat secara otonom, dan tidak membutuhkan peran negara. Bahkan kalau Negara melakukan intervensi dalam formalisasi syariat sangat dimungkinkan akan mereduksi substansi syariah. Sedangkan dari partai, hampir mayoritas partai besar menolak formalisasi syariat, seperti PDIP, Golkar, PKB,PAN. baca Zuhairi Misrawi,» Dekonstruksi Syariat; Jalan Menuju Desakralisasi, Reinterpretasi dan Depolitisasi» dalam Tashwirul Afkar Jurnal Refleksi Pemikiran Keagamaan \& Kebudayaan tema Deformalisasi Syariat Islam, edisi No.12 Tahun 2002 ( Jakarta: Lembaga Kajian dan Pengembangan Sumberdaya Manusia NU dan The Asia Foundation), h.7.

${ }^{64}$ Arus ini sebenarnya minoritas. Yang paling getol mengkampanyekan gagasan moderat ini adalah $\mathrm{KH}$ Shalahuddin Wahid, yang ingin mengambil jalan tengah dari perdebatan yang berseberangan. Akan tetapi sulit rasanya gagasan ini mendapatkan dukungan, karena - sebagaimana gagasan moderat lainnya-hanya berkutat pada tataran moralitas, kehilangan kerangka strategis dan sulit diterapkan pada tataran praksis, baca Zuhairi Misrawi," Dekonstruksi Syariat; Jalan Menuju Desakralisasi, Reinterpretasi dan Depolitisasi” dalam Tashwirul Afkar Jurnal Refleksi Pemikiran Keagamaan \& Kebudayaan tema Deformalisasi Syariat Islam, edisi No.12 Tahun 2002 (Jakarta: 
menolak sekularisasi dan islamisasi, karena budaya masyarakat muslim Indonesia mempunyai kekhasan tersendiri. Sekularisasi dan Islamisasi merupakan barang impor yang tidak cocok dengan identitas masyarakat, sehingga keduanya berpotensi untuk melakukan indoktrinsasi dan ideologisasi. ${ }^{65}$

Akan tetapi terlepas dari pro dan kontra terhadap gagasan formalisasi syariat Islam di atas, yang jelas kesulitan dalam merealisasikan formalisasi syariat tersebut di atas hingga kini, belum ada satu negara pun di dunia yang dapat dipakai sebagai acuan dalam pelaksanaan syariat Islam. ${ }^{66}$ Di samping itu, persoalan mendasar yang perlu dipertanyakan berkaitan dengan formalisasi syariat ini adalah menyangkut level atau ruang lingkup kehidupan, apakah formalisasi syariat Islam diberlakukan untuk mengatur kehidupan individu, masyarakat dalam arti komunitas (kelompok) tertentu atau warga negara Indonesia secara keseluruhan? Tiga persoalan ini penting dipertanyakan karena perdebatan seputar formalisasi syariat Islam yang muncul selama ini di Indonesia kurang menyentuh tiga persoalan tersebut. Persoalan mendasar lainnya yang dihadapi para pendukung formalisasi syariat Islam di Indonesia adalah masalah pengertian atau definisi syariat Islam itu sendiri, karena tanpa proses pendefinisian yang jelas, dapat dan dalam kebanyakan kasus akan bertabrakan dengan prinsip-prinsip hak asasi manusia. ${ }^{67}$ Tiga aspek hak asasi manusia yang paling banyak berkaitan dengan penerapan dan formalisasi syariat Islam adalah pembatasan terhadap kebebasan beragama, diskriminasi terhadap perempuan, dan diskriminasi terhadap Non-Muslim. ${ }^{68}$

\section{PENUTUP}

Pro dan kontra tentang formalisasi syariat Islam yang cukup gencar hingga saat ini. Perdebatan formalisasi syariat Islam di Indonesia dengan kembali mengusulkan Piagam Jakarta ke dalam amandemen UUD 1945. Lebih dari itu, sejumlah Ormas Islam -minus Nahdlatul Ulama dan Muhammadiyah- menyuarakan aksi tuntutan kembalinya Piagam Jakarta, yang berarti pula formalisasi syariat Islam di tanah air. Disisi lain, ada juga

Lembaga Kajian dan Pengembangan Sumberdaya Manusia NU dan The Asia Foundation), h.7. baca juga Salahuddin Wahid,"Negara Sekuler No! Negara Islam No!” dalam Kurniawan Zein dan Sarifuddin (editor). 2001. Syariat Yes Syariat No Dilemma Piagam Jakarta dalam Amandemen UU 1945. (Jakarta:Paramadina), h.23-28.

${ }^{65}$ Zuhairi Misrawi,” Dekonstruksi Syariat; Jalan Menuju Desakralisasi, Reinterpretasi dan Depolitisasi” dalam Tashwirul Afkar Jurnal Refleksi Pemikiran Keagamaan \& Kebudayaan tema Deformalisasi Syariat Islam, edisi No.12 Tahun 2002 ( Jakarta: Lembaga Kajian dan Pengembangan Sumberdaya Manusia NU dan The Asia Foundation), h.7.

${ }^{66}$ Azyumardi Azra, 'Belum Ada Negara Sebagai Acuan Pelaksanaan Syariat Islam,' dalam Kurniawan Zein dan Sarifuddin HA ( Editor). Syariat Islam Yes Syariat Islam No Dilema Piagam Jakarta dalam Amandemen UUD 1945 (Jakarta: Penerbit Paramadina, 2001.). h.183.

${ }^{67}$ Harun Nasution “ Pengantar” dalam Harun Nasution dan Bahtiar Effendy (Penyunting), Hak Azasi Manusia dalam Islam. (Jakarta: Yayasan Obor Indonesia dan Puataka Firdaus, 1995). h, VI-XIV

${ }^{68}$ Anthony J. Nitko and Susan Brookhart, Educational Assessment, p. 1-576. 
kelompok Islam yang menolak formalisasi syariat Islam. Namun faktanya formalisasi ini tidak ditolak secara utuh, buktinya undang-undang perkawinan, undang-undang haji, dan sebagainya diterima dengan baik tanpa ada bantahan. Terlepas dari pro dan kontra terhadap gagasan formalisasi syariat Islam di atas, yang jelas belum ada satu negara pun di dunia yang dapat dipakai sebagai acuan dalam pelaksanaan syariat Islam.

\section{DAFTAR PUSTAKA}

Abdilah, Masykuri Islam dan Demokrasi, Respons Intelektual Muslim Indonesia Terhadap Konsep Demokrasi 1966-1993, (Jakarta: Kencana, 2015).

Abdilah, Masykuri "Hubungan Agama Dan Negara Dalam Konteks Modernisasi Politik Di Era Reformasi”. Jurnal Ahkam, Vol. XIII No. 2 (Juli 2013).

Abdilah, Masykuri NU Tidak Menolak Formalisasi Syariat Islam, http://www.nu.or.id/post/read/8263/nu-tidak-menolak-formalisasi-syariat-islam diakses tanggal 19 Oktober 2018.

Ahmad, Kamaruzzaman Bustamam Wajah Baru Islam Indonesia (UII Press, Yogyakarta, 2004)

Arif, Saiful Islam, Pancasila dan Deradikalisasi: Meneguhkan Nilai Keidonesiaan, (Jakarta: Elex Media Komputindo, 2018)

Asmaroini, Ambiro Puji "Menjaga Eksistensi Pancasila Dan Penerapannya Bagi Masyarakat Di Era Globalisasi," JPK: Jurnal Pancasila dan Kewarganegaraan, Vol. 2, No. 1, Januari 2017 E-ISSN 2527-7057, P-ISSN 2545-2683

Asad, Muhammad Minhaj al-Islam fi al-Hukmi, terjemahan Indonesia, Sebuah Kajian tentang Sistem Pemerintahan Islam, (Bandung : Pustaka, 1985)

Awwas, Irfan Suryahardi "Menerapkan Piagam Cerdas" dalam Kurniawan Zein dan Sarifuddin (editor). 2001. Syariat Yes Syariat No Dilemma Piagam Jakarta dalam Amandemen UU 1945. (Jakarta: Paramadina)

Azra Azyumardi “Belum Ada Negara Sebagai Acuan Pelaksanaan Syariat Islam,' dalam Kurniawan Zein dan Sarifuddin HA (Editor). 2001. Syariat Islam Yes Syariat Islam No Dilema Piagam Jakarta dalam Amandemen UUD 1945 (Jakarta: Penerbit Paramadina)

Budiardjo, Miriam Dasar-Dasar Ilmu Politik, (Jakarta : Gramedia, 1986)

Barakatullah, Abd. Halim dan Teguh Prasetyo Hukum Islam Menjawab Tantangan Zaman Yang Terus Berkembang, (Yogyakarta, Pustaka Pelajar, 2015)

Brusse, Wendy Asbeek dan Jan Schoonebom, Islamic Activism and Democratization, dalam ISIM (International Institute For The Study Of Islam In The Modern World) REVIEW 18, 2006 
Burhanuddin (editor). 2003. Syariat Islam Pandangan Muslim Liberal. (Jakarta: Jaringan Islam Liberal dan The Asia Foundation)

Dahrendorf, Ralf. Is secularism coming to an end?, The Jakarta Post, November 15, 2006.

Djiwandono, J.Soedjati Misinterpreted Democracy may Lead to Tyranny, The Jakarta Post, Okt.6, 2006.

Effendi, Bahtiar "Islam dan Demokrasi: Mencari Sebuah Sintesa Yang memungkinkan", dalam Nasir Tamara (edt), Agama dan Dialog Peradaban, (Jakarta: Paramadina, 1996)

al-Faruqi, Ismail Raji dan Louis Lamya al-Faruqi, Atlas Budaya Menjelajah Khazanah Peradaban Gemilang(Bandung: Mizan, 2015)

Haris, Syamsuddin Masalah-Masalah Demokrasi dan Kebagsaan Era Reformasi, (Jakarta: Yayasan Pustaka Obor Indonesia, 2015)

Husaini, Adhian dan Nuim Hidayat. Islam Liberal: Sejarah, Konsepsi, Penyimpangan, dan Jawabannya. (Jakarta: Gema Insani Press, 2009)

Hosen, Nadirsyah Shari'a and Constitutional Reform in Indonesia (Singapore: ISEAS, 2007)

Huda, Ni'matul dkk, Teori dan Hukum Konstitusi, (Jakarta: Rajawali Press, 2014)

Kamali, Mohammad Hashim Shari'ah Law: An Introduction, (Oxford: Oneworld, 2008)

Kafid, N “Dari Islamisme ke ' Premanisme ': Pergeseran Orientasi Gerakan Kelompok Islam Radikal di Era Desentralisasi Demokrasi 1,” MASYARAKAT: Jurnal Sosiologi 21, no. 1 (2016): 57-79, http://journal.ui.ac.id/index.php/mjs/article/ view/4737.

Kurzman, Charles (editor). Wacana Islam Liberal Pemikiran Islam Kontemporer dan IsuIsu Global, terjemahan Bahrul Ulum dari Liberal Islam: A Sourcebook. (Jakarta: Paramadina, Yayasan Adikarya IKAPI dan The Ford Foundation, 2001)

Lewis, Bernard Islam and The West (New York: The Oxford University Press, 1991)

Lufaefi "Rekontruksi Jargon Formalisasi Syariat: Upaya Menjaga Persatuan Dalam Bingkai Keragaman” Al-A'raf: Jurnal Pemikiran Islam - Vol. XIV, No. 1, Januari - Juni 2017.

Mahendra,Yusril Ihza "Hukum Islam Dan Pengaruhnya Terhadap Hukum Nasional Indonesia," www.yusril.ihzamahendra.com, diakses pada 10 Oktober 2018.

Mahfud MD, Moh "Ceramah Kunci Ketua Mahkamah Konstitusi" Dalam tim Penyusunan Studi Pancasila UGM dan Universitas Patimura Ambon, Prosiding kongres Pancasila VI: Penguatan, Singkronisasi, Harmonisasi, Memperkokoh Kedaulatan Bangsa, (Yogyakarta: PSP UGM, 2014)

Man̄̄ūr, Ibn Lisān al-'Arab (Beirut: Dār al-Kutub al-'ilmiyyah, jilid 5, cet. 1)

Marzuki "Tinjauan Umum Tentang Hukum Islam”, Makalah di Sampaikan pada Seminar PSP Nusantara 2016.

al-Mawardi al-Ahkam as-Sultaniyyah, (Beirut: Dar al-Fikr, 1981) 
Misrawi, Zuhairi "Dekonstruksi Syariat; Jalan Menuju Desakralisasi, Reinterpretasi dan Depolitisasi” dalam Tashwirul Afkar Jurnal Refleksi Pemikiran Keagamaan \& Kebudayaan tema Deformalisasi Syariat Islam, edisi No.12 Tahun 2002 (Jakarta: Lembaga Kajian dan Pengembangan Sumberdaya Manusia NU dan The Asia Foundation)

Muhammad Natsir, Capita Selekta, (Jakarta: Bulan Bintang, 1954)

Musa, Muhammad Yusuf Nizhamul Hukmi Fil Islam, (Kairo : Darul Katib al-'Arabiy, 1965)

Ma'arif, Ahmad Syafi'I “Strategi Pelambangan Nilai-NIlai Pancasila dalam Perspektif Agama, Sosial dan Budaya”. Dalam tim penyusunan Studi Pancasila UGM dan Universitas Patimura Ambon, Prosiding kongres Pancasila VI: Penguatan, Singkronisasi, Harmonisasi, Memperkokoh Kedaulatan Bangsa, (Yogyakarta: PSP UGM, 2014)

An-Nabhani, Taqiyuddin Nizham Al-Hukm (Beirut: Hizbut Tahrir, 2002).

Nasution, Harun "Pengantar" dalam Harun Nasution dan Bahtiar Effendy (Penyunting),

Hak Azasi Manusia dalam Islam. (Jakarta: Yayasan Obor Indonesia dan Puataka Firdaus, 1995)

Osman, Fathi "Bay'ah al-Imam: Kesepakatan Pengangkatan Kepala Negara Islam,” dalam Mumtaz Ahmad (ed.). Masalah-Masalah Teori Politik Islam (Bandung: Mizan, 1993)

al-Qathan, Manna' al-Tasyri' wa al-Fiqh fi al-Islam, (Muassasahal-Risalah 2002).

Rahardjo, Dawam "Ekonomi Islam, Ekonomi Pancasila dan Pembangunan Ekonomi Indonesia, dalam Ainur R. Sophian (edt), Etika Ekonomi Politik, (Surabaya: Risalah Gusti, 2014).

Rahardjo, Dawam "Kritik Nalar Negara Islam” Islamlib.com. diakses tanggal 10 Oktober 2018

Sjadzali, Munawir Islam dan Tata Negara (Jakarta: UI press, 1991) Suhendra, Ahmad Penguatan Nilai-Nilai Kebangsaan dan Pancasila dalam Menangkal Benih Radikalisme di Kalangan Pelajar Tangerang, (Tangerang: PSP Nusantara Press, 2018)

Sulaiman, Rio Pemikiran dan Kiprah Majelis Mujahidin Indonesia (UIN Syarif Hidayatullah, Jakarta, 2016)

Syaltut, Mahmud Al-Islam Aqidah wa Syariah, (Beirut : Dar al-Fikr 2004).

Syalabi, Muhammad Musthafa Al-Madkhal Fi at-Ta'rif bi al-Fiqh al-Islami, (Dar alNahdhah al-Arabiyah,1969)

Taimiyah, Ahmad bin Abdul Halim al-Hisbah fi al-Islam aw Wadhifatu al-Hukumiyah alIslamiyyah, (Beirut : Dar al-Kutub al-'Ilmiyyah, 1992). 
Taimiyah, Ahmad bin Abdul Halim, al-Siyasah al-Syar'iyyah Fi Ishlahi al-Ra'iy wa alRa iyyah, (Beirut: Dar al-Jail, 1993)

Tibi, Bassam Islam and a Cultural Accomodation in Social Change (Bouldier: Westview Press, 1990)

Yusuf Ali, Abdullah The Holy Al-Quran: Text, Translation and Commentary (Brenwood: Maryland Amana Corporation, 1989). 